\title{
IMPLEMENTASI KEBIJAKAN UPAH MINIMUM KABUPATEN (UMK) DI KABUPATEN KEBUMEN
}

\section{Endah Wahjoe Widajati ${ }^{1}$, Slamet Rosyadi' ${ }^{2}$, Wahyuningrat ${ }^{2}$}

${ }^{1}$ Mahasiswa Program Studi Magister Administrasi Publik, FISIP, Universitas Jenderal Soedirman 2Dosen Program Studi Magister Administrasi Publik, FISIP, Universitas Jenderal Soedirman

\begin{abstract}
Abstrak
Penelitian ini tentang permasalahan implementasi UMK di Kabupaten Kebumen yang sangat komplek apabila dilihat dari formulasi kebijakan, proses kebijakan dan dampak kebijakan memunculkan beberapa masalah yang menyebabkan implementasi UMK sulit dilaksanakan. Dalam tulisan ini akan mengkaji implementasi Upah Minimum Kabupaten yang dipengaruhi perilaku hubungan antar organisasi pelaksana yaitu komitmen dan koordinasi dalam organisasi SPSI/PUK, perilaku implementor yaitu peran kontrol dan profesional dari pemerintah serta pengusaha dan perilaku kelompok sasaran Respon terhadap norma dan peraturan perburuhan, dan kepuasan kerja dari buruh. Penelitian ini menggunakan desain survei dengan pendekatan kuantitatif. Teknik pengumpulan data diperoleh dengan kuesioner, wawancaradan dokumentasi. Dalam penelitian ini teknik sampling digunakan adalah Proposional Cluster Random Sampling. Berdasarkan hasil penelitian dapat disimpulkan sebagai berikut : pertama, terdapat pengaruh positif dan signifikant perilaku hubungan antara organisasi pelaksana terhadap Implementasi Upah Minimum Kabupaten dengan koefisien korelasi sebesar 0,690; kedua, terdapat pengaruh positif dan signifikan perilaku implementor terhadap implementasi Upah Minimum Kabupaten dengan koefisien korelasi sebesar 0,864; ketiga, terdapat pengaruh positif dan signifikan pengaruh antara variabel perilaku kelompok sasaran terhadap implementasi Upah Minimum Kabupaten dengan koefisien korelasi sebesar 0,846; keempat, terdapat pengaruh positif dan signifikan perilaku kelompok sasaran dengan implementasi upah minimum kabupaten dengan kofisien korelasi sebesar 0,846; kelima, pengaruh bersama-sama perilaku hubungan antar organisasi pelaksana PUK/SPSI sebagai organisasi pekerja agar meningkatkan komitmen dan koordinasinya bersama variabel perilaku implementor dan perilaku kelompok sasaran terhadap Implementasi Upah Minimum kabupaten dengan koefisien korelasi sebesar 16.131.

Kata Kunci: Perilaku hubungan antar organisasi, keberhasilan implementasi, perilaku implementor dan perilaku kelompok sasaran
\end{abstract}

\section{PENDAHULUAN}

Pada hakikatnya implementasi menjadi tahap yang sangat menentukan dalam proses kebijakan karena tanpa implementasi yang efektif, maka keputusan pembuat kebijakan dianggap tidak akan berhasil dilaksanakan. Implementasi kebijakan merupakan aktivitas yang terlihat setelah adanya pengarahan yang sah dari suatu kebijakan yang meliputi bagaimana upaya mengelola input untuk menghasilkan output atau outcomes.

Setiap individu menginginkan kehidupan yang baik, bekerja untuk mencapai kehidupan yang layak. Upah Minimum Kabupaten sebagai bentuk kebijakan yang dituangkan dalam Keputusan Gubernur Jawa Tengah nomor: 560/66 tahun 2015 tentang upah minimum pada 35 (tiga puluh lima) kabupaten kota, yang tentunya bersumber dari Undang-Undang Nomor 13 Tahun 2013 Tentang Ketenagakerjaan. Upah Minimum Kabupaten merupakan bentuk 
kebijakan sosial yang dapat menjamin standar kesejahteraan hidup minimum bagi setiap warga negaranya. Disamping itu kebijakan ini bertujuan untuk menghindari permasalahan hubungan kerja. Pemerintah melakukan intervensi dengan cara mengeluarkan kebijakan yang mengatur mengenai upah minimum kota/kabupaten (UMK), jaminan sosial tenaga kerja (Jamsostek), hubungan industrial, upah lembur, jam kerja dan istirahat serta tunjangan hari raya. Standar kebutuhan juga harus dipenuhi oleh seorang pekerja atau buruh lajang untuk dapat hidup layak baik secara fisik, non fisik dan sosial, untuk kebutuhan 1 (satu) bulan yang kemudian dapat dijadikan ukuran dalam Kebutuhan Hidup Layak (KHL).

Dari tahun ke tahun Upah Minimum Kabupaten mengalami kenaikan, namun rata-rata kenaikan Upah Minimum Kabupaten setiap tahun tidak lebih dari 1,2\%, sebagaimana dapat dilihat dari data kenaikan UMK selama lima tahun terakhir dalam tabel 2 di bawah ini.

Tabel 1. Upah Minimum Kabupaten Lima Tahun Terakhir Sebagai Dasar Penetapan UMK

\begin{tabular}{cccc} 
TAHUN & KHL & UMK & \% UMK/KHL \\
\hline 2012 & 797.418 & 770.000 & $94,44 \%$ \\
2013 & 815.312 & 835.000 & $95,70 \%$ \\
2014 & 870.840 & 975.000 & $101,17 \%$ \\
2015 & 963.715 & 1.157 .500 & $100,03 \%$ \\
2016 & 1.286 .949 & 1.324 .600 & $101,4 \%$ \\
\hline
\end{tabular}

\section{Sumber dari Disnakertransos Kab. Kebumen Tahun 2016}

Besar dan kecilnya upah buruh berpengaruh terhadap tingkat kesejahteraannya. Data dari Biro Pusat Statistik, Kabupaten Kebumen menduduki kategori miskin peringkat terendah kedua di Jawa Tengah, dengan jumlah penduduk miskin mencapai 265.163 jiwa atau 22,4 persen dari jumlah penduduk. Terkait dengan hal tersebut maka buruh dengan penghasilan kecil atau di bawah UMK juga ikut menyumbang besarnya angka kemiskinan di Kabupaten Kebumen.

Menurut Kepala Bidang Hubungan Industrial dan Pengawasan Tenaga Kerja pada Dinas Tenaga Kerja Transmigrasi dan Sosial Kabupaten Kebumen menyatakan bahwa faktor penghambat pada penetapan upah minimum kabupaten adalah : (1) Pihak dewan pengupahan terlalu berat ke pihak pengusaha; (2) Kesejahteraan pihak pekerja kurang diperhatikan oleh para pengusaha; (3) Nilai tawar pekerja sangat lemah karena ancaman PHK; (4) Produktifitas pekerja menjadi alasan pengusaha membayar dibawah UMK. Kecilnya atau upah di bawah UMK lebih dikarenakan posisi tawar (bargaining position) buruh yang sangat lemah, dalam hal ini menunjukkan perilaku buruh/pekerja sebagai kelompok sasaran yang seolah-olah pasrah dengan posisi tawar yang rendah. wawancara, tanggal 15 September 2015).

Data yang dari Dinas Tenaga Kerja dan Transmigrasi Kabupaten Kebumen menunjukkan bahwa Upah Minimum Kabupaten belum sepenuhnya dilaksanakan oleh perusahaan, dari jumlah 681 perusahaan 30\% sampai dengan 40\% memberikan upah di bawah Upah Minimum Kabupaten dan satu perusahaan melaksanakan penundaan terkait dengan upah minimum. 
Tabel 2. Data Pelaksanaan UMK Perusahaan di Kabupaten Kebumen Tahun 2015

\begin{tabular}{clcc}
\hline \multirow{2}{*}{ NO } & \multirow{2}{*}{ PELAKSANAAN UMK } & JUMLAH PERUSAHAAN & $\begin{array}{c}\text { PROSENTASE } \\
\text { PERUSAHAAN }\end{array}$ \\
\hline 1 & Seluruh Karyawan & 189 & $27,7 \%$ \\
2 & Sebagian karyawan & 79 & $11,6 \%$ \\
3 & Tidak menerapkan & 412 & $60,5 \%$ \\
4 & Penangguhan & 1 & $0,14 \%$ \\
& JUMLAH & 681 & \\
\hline
\end{tabular}

Data hasil monitoring Disnakertransos Kab. Kebumen Tahun 2016

Dari data diatas ada 10.262 yang bergantung hidupnya disektor industri dan ada 4.638 pekerja yang diupah dibawah UMK sebagai pekerja kalau asumsi mempunyai 4 orang tiap kepala keluarga berarti ada 18.552 jiwa yang hidup dengan standar dibawah UMK. Dari data tersebut masih 60,5\% dengan 4.105 orang karyawan yang belum melaksanakan UMK sedangkan yang sepenuhnya melaksanakan UMK hanya 27,7 \% dengan 3.549 karyawan dan yang hanya sebagian di gaji UMK ada 11,6\% dengan 2.149 karyawan sehingga hanya 5.624 orang diupah dengan UMK dan 3.564 orang tidak diberi upah dengan UMK. Menurut Kepala Bidang Hubungan Industrial dan Pengawasan Tenaga Kerja pada Dinas Tenaga Kerja Transmigrasi dan Sosial Kabupaten Kebumen yang tidak melaksanakan adalah karena ratarata perusahaan yang terdaftar di Kabupaten Kebumen adalah kategori kecil atau sedang. Karakteristik perusahaan di Kebumen banyak yang padat karya dengan hasil produksi bersifat lokal seperti pabrik genteng dan perusahaan penggilangan padi merupakan perusahaan skala kecil. Upah/gaji yang diterapkan lebih banyak menggunakan sistem harian yang dibawah UMK. Sedangkan yang melaksanakan UMK penuh ada beberapa perusahaan yang merupakan anak cabang perusahaan multinasional dan sebagian jasa perbankan serta dibidang perhotelan. Sementara yang menerapkan sebagian adalah perusahaan yang merupakan perusahaan padat karya tetapi produktifitasnya rendah dan masuk kategori perusahaan menengah dan besar.

Adanya konsep upah minimum bagi pekerja yang tepat yakni dengan dilibatkannya pekerja yang dapat diwakili serikat pekerja. Transparansi perusahaan menjadi kunci utama, karena pengusaha tahu betul situasi dan kondisi perusahaannya. Perusahaan dapat pula menunjukkan laporan keuangan yang telah diaudit kepada serikat pekerja dan serikat pekerja harus mampu membaca serta menganalisis laporan keuangan dari perusahaan. Dari fenomena-fenomena tersebut ada kecenderungan bahwa implementasi kebijakan UMK tidak selaras dalam pelaksanaannya, maka dapat dikaji sejauhmana perilaku organisasi pelaksana yaitu peran dewan pengusaha atau Asosiasi Pengusaha Indonesia (APINDO) dan organisasi serikat pekerja yang menjadi wadah dalam menyuarakan hak, atau mewakili anggotanya dalam membentuk sikap, motivasi, maupun kepuasan anggotanya terhadap situasi yang dihadapi.

Melihat permasalahan tersebut dapat diasumsikan bahwa kebijakan tidak dapat dilihat secara terpisah dari perilaku organisasi pelaksananya. Adapun yang dimaksud dalam hal ini 
adalah aktor-aktor yang terkait dalam unsur-unsur stakeholders yang memperjuangkan kepentingan masing-masing. Berkaitan dengan proses implementasi kebijakan pengupahan buruh Kabupaten Kebumen tahun 2016 maka pihak-pihak yang terlibat dalam pelaksanaan kebijakan tersebut adalah pengusaha, buruh/pekerja dan pegawai pengawas ketenagakerjaan sebagai penegak hukum apabila terjadi pelanggaran-pelanggaran ketenagakerjaan.

Dari tiga unsur tripartit yaitu unsur pemerintah, unsur pengusaha (APINDO) dan unsur buruh/pekerja yang diwakili SPSI maka unsur buruh/pekerja yang lebih terdampak dari kebijakan UMK mengingat pengusaha akan mempertahankan keuntungan perusahaannya, sementara pemerintah mempunyai kepentingan terhadap iklim hubungan industrial yang kondusif. Peran organisasi buruh/pekerja akan sangat membantu perjuangan dalam penentuan UMK, namun dari data Disnakertransos Kebupaten Kebumen hanya ada 25 Pengurus Unit Kerja SPSI (PUK SPSI) sebagaimana data berikut:

Tabel 3. Data PUK SPSI Perusahaan di Kabupaten Kebumen Tahun 2015

\begin{tabular}{ccc}
\hline JUMLAH PERUSAHAAN & JUMLAH PUK SPSI & JUMLAH BURUH \\
\hline 681 & 25 & 10.262 \\
\hline
\end{tabular}

Data hasil monitoring Disnakertransos Kab. Kebumen Tahun 2015

Dari data diatas maka dapat dilihat sangat sedikit yang membentuk unit SPSI di perusahaan, hanya ada 3,7 \% dari 681 perusahaan yang sebagian besar ada di perusahaan yang merupakan cabang atau perusahaan besar. Sedangkan berdasarkan aturan minimal 10 orang buruh dalam satu perusahaan bisa membentuk 1 (satu) PUK.

Berkaitan dengan sejumlah fakta di atas, maka peneliti tertarik untuk mendalaminya melalui penelitian ini dengan menggunakan teori-teori yang dapat mengungkapnya. Tahapan implementasi banyak menarik perhatian para pakar untuk mengembangkan teori-teori atau pendapat tentang kiat-kiat implementasi kebijakan yang efektif. Hubungan yang komplek antara berbagai variabel independen, dengan variabel dependen (kinerja implementasi kebijakan) tersebut banyak dibahas oleh para ahli implementasi diantaranya: Smith, Quade, Shabbier Cheema, David L Weimer \& Ardan R Vinning, Van Metter dan Carl E. Van Horn.

Mengingat permasalahan di Kabupaten pada lemahnya organisasi utamanya organisasi buruh/pekerja maka pendekatan yang dipergunakan adalah dari Soren C. Winter dalam Peters and Pierre yaitu memperkenalkan model implementasi integratif (Integrated Implementation Model). Winter menyatakan bahwa adanya keberhasilan implementasi kebijakan dipengaruhi oleh formulasi kebijakan, proses implementasi kebijakan dan dampak/hasil implementasi kebijakan itu sendiri. Selanjutnya Soren C Winter juga menyampaikan 3 (tiga) variabel yang mempengaruhi keberhasilan pada proses implementasi diantaranya 1) Perilaku hubungan antar organisasi, di mana dimensinya berupa komitmen dan koordinasi antar organisasi; 2) Perilaku implementor (aparat/birokrat) tingkat bawah, yang mana dimensinya adalah kontrol politik, kontrol organisasi dan etos kerja dan norma-norma profesional; 3) Perilaku kelompok 
sasaran. Kelompok sasaran sendiri tidak hanya memberi pengaruh pada dampak kebijakan, namun juga mempengaruhi kinerja aparat tingkat bawah, jika dampak yang ditimbulkan baik maka kinerja aparat tingkat bawah juga baik demikian dengan sebaliknya. Adapun perilaku kelompok sasaran terdiri dari respon positif atau negatif masyarakat dalam mendukung atau tidak mendukung suatu kebijakan yang disertai adanya umpan balik berupa tanggapan kelompok sasaran terhadap kebijakan yang dibuat.

\section{METODE PENELITIAN}

Metode penelitian yang digunakan dalam penelitian ini adalah survei dengan pendekatan kuantitatif. Penelitian ini akan mengambil sample di 25 perusahaan di Kebumen. Sasaran penelitian ini adalah PUK sejumlah 128 orang responden, penentuan jumlah sampel dapat dilakukan dengan cara menghitung statistic yaitu dengan tabel yang disusun oleh Krejcie dan Morgan. Teknik pengumpulan data dilakukan melalui kuesioner, wawancara dan dokumentasi. Teknik analisis data menggunakan Korelasi Product Moment, Regresi Linear Sederhana dan Regresi Linear Berganda. Variabel independen adalah perilaku hubungan anar orgabisasi, perilaku implementor, perilaku kelompok sasaran variabel dependen adalah implementasi kebijakan upah minimum di Kebumen.

\section{HASIL DAN PEMBAHASAN}

Penelitian ini dilakukan pada perusahaan yang tercatat di Dinas Tenaga Kerja dan Transmigrasi Kabupaten Kebumen dengan sasaran pekerja. Di Kabupaten Kebumen terdapat 681 perusahaan dengan jumlah pekerja 10.262 orang. Sebanyak 11 unit, rata-rata perusahaan yang terdaftar di Kabupaten Kebumen adalah kategori kecil atau sedang. Karakteristik perusahaan di Kabupaten Kebumen banyak yang padat karya dan hasil produksi bersifat lokal seperti pabrik genteng dan perusahaan penggilangan padi skala kecil. Upah/gaji yang diterapkan lebih banyak menggunakan sistem harian yang dibawah UMK. Sedangkan penerapan pembayaran berdasarkan UMK dilakukan oleh beberapa perusahaan yang merupakan anak cabang perusahaan multinasional dan sebagian Jasa perbankan serta dibidang perhotelan.

Jumlah total responden dalam penelitian ini adalah 128 responden yang terdiri dari Pengurus Unit Kerja (PUK) atau Unit SPSI pada suatu perusahaan dengan obyek penelitian 25 perusahaan. Penelitian ini menggunakan teknik pengumpulan data berupa kuesioner sebagai instrumen pengumpul data primer. Adapun data primer yang dimaksud yaitu jawaban dari responden atas daftar pertanyaan atau pernyataan yang tertera pada 55 item kuesioner tersebut. Kuesioner terbagi dalam tiga bagian meliputi bagian pertama yang berisi surat permohonan kesediaan menjadi responden, bagian kedua yang berisi mengenai identitas 
responden yang nantinya akan diolah menjadi karakteristik responden, dan bagian ketiga yang berisi daftar pertanyaan atau pernyataan.

Pada penelitian ini gambaran umum responden dapat dilihat dari data Jenis kelamin, usia, status pernikahan, penghasilan, dan tunjangan yang diterima responden. Responden yang terjaring dalam penelitian didominasi oleh laki-laki yaitu dari 128 terdapat 30 (23,4\%) responden perempuan dan 98 (76,6\%) responden laki-laki. 60,2\% atau 77 responden berusia antara 31 sampai dengan 40 tahun atau usia produktif. Sedangkan status perkawinan 91,4\% atau 117 responden sudah menikah dan hanya 8,6\% atau 11 orang belum nikah. Untuk kategori lama bekerja lebih banyak yang bekerja selama 5 tahun yaitu 40,6\% atau 52 responden, lama bekerja 3 tahun ada 10,2\% atau 13 responden yang lain lama bekerja bervariasi antara 1 sampai dengan 23 tahun .

Banyak faktor yang mendorong pengusaha tidak membayar sesuai UMK selain variabel yang diujikan juga adanya kompentensi pekerja yang rendah, sebagian perusahaan adalah perusahaan perorangan. Walaupun pemberian gaji yang dibawah UMK tetapi pekerja masih mendapatkan tunjangan baik berupa THR (Tunjangan Hari Raya), tunjangan kesahatan dan juga bonus-bonus lainnya, dari data terlihat pengusaha lebih konsekuen dalam membayar tunjangan pekerja yaitu $75 \%$ atau 96 telah mendapat tunjangan dan $25 \%$ atau 32 responden yang tidak mendapat tunjangan dari perusahaan.

Analisis data diskriptif bertujuan untuk menggambarkan kecenderungan atas jawaban responden terhadap pertanyaan-pertanyaan yang diajukan dalam kuesioner mengenai masingmasing variabel. Dengan demikian, hasil jawaban tersebut selanjutnya digunakan untuk mendapatkan tendensi jawaban responden mengenai kondisi masing-masing variabel sehingga diperoleh kecenderungan jawaban responden terhadap jawaban masing-masing variabel yang akan didasarkan pada rentang skor jawaban.

Pernyataan pada kuesioner diukur menggunakan skala 1-5. Kemudian untuk mendapatkan data yang bersifat interval, jika dimasukkan dalam rentang kategori skor, ratarata tersebut dapat dikategorikan sebagai berikut.

Tabel 4. Perhitungan kategori skor

\begin{tabular}{|ll|ll|} 
Skor minimal $=1$ & Rentang kategori skor \\
Skor maksimal $=5$ & $1,00-1,8$ & $=$ sangat buruk \\
Rentang skor & $=\frac{5-1}{5}=0,8$ & $1,9-2,6$ & $=$ buruk \\
& & $2,7-3,4$ & $=$ sedang \\
& $3,5-4,2$ & $=$ baik \\
& $4,3-5,0$ & $=$ sangat baik
\end{tabular}

Sumber: data primer diolah, 2016

Hasil diskripsi implementasi kebijakan Upah Minimum Kabupaten di Kabupaten Kebumen menunjukkan bahwa dari 128 responden dalam menjawab pernyataan, scor nilai rata rata berada pada nilai 4,60 dengan kategori sangat baik dari segi efektivitas, 
responsivitas, akuntabilitas, dan keadilan. Hasil diskripsi variabel perilaku hubungan antar organisasi menunjukkan bahwa dari 128 responden dalam menjawab 13 pernyataan, responden menjawab buruk 53,1\%, dan baik sejumlah 46,9\%,. Apabila dilihat prosentase jawaban maka banyak menjawab buruk sejumlah 53,1\% lebih dominan. Hal ini dapat dimaknai dari indikator penilaian tingkat koordinasi dan komitmen pengurus organisasi PUK/SPSI. Fungsi PUK/SPSI dalam koordinasi dan komitmen belum ada dikarenakan kepengurusan PUK bersifat pasif, hanya sekedar memenuhi kewajiban pembentukan SPSI. Tidak pernah ada pertemuan terlebih untuk saling berkomunikasi tentang permasalahan yang dihadapi baik terkait kesejahteraan maupun upah. Angka 46,9 \% responden menjawab baik dimana Pengurus Serikat Pekerja mengetahui persoalan-persoalan teknis hukum, perburuhan dan konsekuensi yuridis-ekonomis bagi pekerja. Tidak hanya itu, juga dapat melalukan sosialisasi, pendidikan dan advokasi kepada para pekerja. Dengan begitu pekerja akan lebih mudah dan bertanggung jawab dalam melaksanakan hak dan tanggungjawabnya. Disamping ada dialog dan komunikasi dua arah antara pekerja dan pengusaha, hal yang paling serius adalah persoalan kepastian masa depan pekerja, keberadaan jaminan perlindungan hak pekerja serta pemenuhan kebutuhan pekerja.

Hasil deskripsi variabel perilaku implementor menunjukkan bahwa dari 128 responden dalam menjawab 11 pernyataan, bahwa responden menjawab buruk 51,6\% dan baik sebesar 48,4\%, Hal ini dimaknai bahwa indikator kontrol dari organisasi dan profesionalisme pemerintah serta pengusaha terhadap UMK. Apabila dilihat prosentase jawaban buruk sejumlah 51,6\%,\% dikarenakan pemerintah dan APINDO tidak melaksanakan fungsi kontrol dan tidak profesional. Baik dalam proses penentuan UMK maupun dalam pelaksanaan UMK. Dalam proses penentuan UMK buruh merasa tidak dilibatkan. Pemerintah memaksanakan kebijakannya menghadapi kepentingan pengusaha dimana dalam menerapkan UMK dirasakan oleh pekerja masih jauh dari kebutuhan hidup minum (KHM). Pengusaha bertindak sewenang-wenang karena mengusai faktor modal dan faktor produksi. Sikap pengusaha yang cenderung menekan upah pekerja ini sangat terkait dengan cara pandang dan persepsi yang berbeda antara pengusaha dan buruh dalam mendefinisikan upah. Bagi pengusaha upah justru dinilai sebagai beban. Hal ini dikarenakan semakin besar upah yang dibayarkan kepada pekerja maka semakin kecil keuntungan bagi pengusaha. Segala sesuatu yang dikeluarkan pengusaha sehubungan dengan memperkerjakan seseorang dipandang sebagai komponen upah. Pada jawaban kategori baik sebesar 48,4 \% dimaknai bahwa pekerja memandang pengusaha sudah mengkomunikasikan bahkan sudah melaksanakan pembayaran upah sesuai bahkan lebih. Adanya kunjungan dan komunikasi dengan pengawas juga mereka ketahui. Di Kabupaten Kebumen dibagi dua kategori yaitu multinasional yang biasanya padat modal dan pengusaha lokal cenderung padat karya, 
Profesionalisme pengusaha akan terlihat dari karakteristik perusahaan, dimana pengusaha yang padat modal cenderung membayar sesuai dengan kebijakan UMK sedangkan padat karya membayar sebagian atau semua dibawah UMK. Profesionalisme pengusaha penting dalam hal ini karena menyangkut kebijakan perusahaan terutama upah atau UMK.

Hasil deskripsi variabel prilaku kelompok sasaran menunjukkan bahwa dari 128 responden dalam menjawab 10 pernyataan, Respon buruk pada angka 60,9 \% terhadap aturan atau norma serta kepuasan kerja dimaknai bahwa pekerja tidak merasakan imbas terhadap aturan yang melindungi mereka yaitu ada dan tidak ada UMK mereka tidak tahu bahkan setelah tahu bahwa upah mereka di bawah UMK pekerja merasa tidak peduli. Peraturan yang sebenarnya tidak memihak pada pekerja tetapi hal itu diterima karena mereka merasa simbiosis mutualisme dalam penetapan upah pekerja. Mereka merasa yang penting dapat bekerja dan mendapat upah untuk memenuhi kebutuhan hidup, mereka lebih bingung lagi kalau tidak memiliki pekerjaan. Adapun terhadap kepuasan kerja kelompok inipun tidak peduli, dengan alasan yang penting mendapat pekerjaan. Respon baik pada angka 39,1\% dimaknai bahwa pekerja merasa puas terhadap penerapan aturan yang melindungi mereka dan juga puas terhadap upah yang mereka terima sesuai bahkan ada yang melebihi UMK sehingga merasa puas terhadap hasil kerja mereka. Fasiltas perusahaan juga dirasakan sudah menunjang dan melindungi serta memberi kenyamanan bekerja.

Hasil diskripsi variabel implementasi kebijakan upah minimum kabupaten 60,2\% UMK belum dilaksanakan dan 38,85\% sudah melaksanakan UMK. Dari 128 responden tingkat kepuasan terhadap jaminan perlindungan dan pengupahan sudah cukup baik. Walaupun ketentuan pemerintah bahwa UMK adalah berlaku untuk semua pekerja sebagai batas minimal tetapi sebagian pekerja sudah merasa puas dengan ketentuan perusahaan tersebut. Ketentuan kebijakan UMK melalui keputusan Gubernur adalah berlaku bagi seluruh pekerja yang diterima belum sesuai ketentuan UMK dalam pengupahan.

Apabila dilihat prosentase jawaban maka banyak menjawab baik sejumlah 38,85\%. Hal ini bermakna pekerja memandang beban dan tanggung jawab pekerjaan sudah seimbang dengan besaran upah yang diterima. Hal ini merupakan paradog bahwa masih ada 60,2\% yang diberi upah belum sesuai UMK. Hal ini menunjukkan pekerja selalu dalam posisi nilai tawar yang rendah dan tidak berdaya sehingga harus selalu menerima beban pekerjaan walaupun sebenarnya digaji dibawah UMK mereka menerima pekerjaan tersebut karena tidak ada pekerjaan lain. Beban yang dirasakan sesuai adalah sebenarnya semu karena tidak sebanding dengan UMK, hal ini karena dinilai pekerja produktivitasnya rendah oleh pengusaha.

Berdasarkan hal tersebut, untuk mengetahui hubungan antar variabel, maka dilakukan uji korelasi Pearson Product Moment. Kemudian untuk menentukan tingkat hubungan antar 
variabel maka koefisien korelasi yang dihasilkan dibandingkan dengan tabel pedoman interpretasi dan korelasi berikut.

Tabel 5. Pedoman Interpretasi dan Korelasi

\begin{tabular}{ccc} 
No & Interval koefisien & Tingkat Hubungan \\
\hline 1 & $0,00-0,199$ & Sangat Rendah \\
2 & $0,20-0,399$ & Rendah \\
3 & $0,40-0,599$ & Sedang \\
4 & $0,60-0,799$ & Kuat \\
5 & $0,80-1,00$ & Sangat Kuat \\
\hline
\end{tabular}

Sumber: Sugiyono, 2012

Dalam bagian ini akan dibahas hasil-hasil analisis atau pengujian statistik yang bertujuan untuk mengetahui pengaruh variabel bebas secara parsial maupun bersama-sama terhadap variabel terikat. Dari pembahasan ini akan diketahui signifikan tidaknya pengaruh variabel bebas terhadap variabel terikat sehingga pada akhirnya dapat pula diketahui apakah hipotesis yang diajukan dalam penelitian ini terbukti atau tidak, dengan tingkat kesalahan 0,05 (5\%).

\section{Uji Korelasi Product Moment}

Tabel 6. Korelasi Product Moment

\begin{tabular}{lcccc}
\hline & & & & \\
& & $Y$ & X & Tingkat Hubungan \\
\hline Pearson & Y (IUMK) & 1.000 & .832 & Sangat kuat \\
Correlation & X1 (PHAOP) & .832 & 1.000 & \\
& Y (IUMK) & 1.000 & .864 & Sangat kuat \\
& X1 (PI) & .836 & 1.000 & \\
& Y (IUMK) & 1.000 & .846 & Sangat kuat \\
& X3 (PKS) & .846 & 1.000 & \\
\hline
\end{tabular}

Hasil Korelasi antara variabel Perilaku hubungan antar organisasi pelaksana dengan Implementasi Upah Minimum Kabupaten menunjukkan adanya korelasi yang sangat kuat antara kedua variabel tersebut dengan arah positif.

\section{Uji Determinasi}

Dalam penelitian ini Koefiesien determinasi $\left(\mathrm{R}^{2}\right)$ berdasarkan perhitungan regresi linier sederhana, maka digunakan $\mathrm{R}^{2}$ yang sudah disesuaikan (Adjusted $\mathrm{R}^{2}$ ). Koefisien korelasi tersebut menunjukan adanya korelasi yang kuat antara perilaku hubungan organisasi pelaksana dengan Implementasi Upah Minimum Kabupaten dengan arah positif. sebagaimana tabel berikut: 
Tabel 7. Koefisien Determinasi

\begin{tabular}{|c|c|c|c|c|}
\hline Variabel & $\mathrm{R}$ & $\mathrm{R}$ Square & Adjusted R Square & $\begin{array}{c}\text { Std. Error of the } \\
\text { Estimate }\end{array}$ \\
\hline $\mathrm{X} 1$ & $.832^{\mathrm{a}}$ & .693 & .690 & 7.865 \\
\hline $\mathrm{X} 2$ & $.864^{\mathrm{a}}$ & .746 & .744 & 7.143 \\
\hline $\mathrm{X} 3$ & $.846^{\mathrm{a}}$ & .716 & .714 & 7.554 \\
\hline
\end{tabular}

\section{Uji Korelasi Parsial}

Dari Uji Korelasi Parsial terdapat korelasi yang rendah antara perilaku kelompok sasaran $\left(\mathrm{x}_{3}\right)$ dengan implementasi upah minimum kabupaten $(\mathrm{y})$ dengan arah positif ketika dikontrol oleh variabel perilaku hubungan antar organisasi $\left(\mathrm{x}_{1}\right)$ dan variabel perilaku implementor $\left(\mathrm{x}_{2}\right)$. Untuk menguji apakah korelasi antara perilaku kelompok sasaran $\left(\mathrm{x}_{3}\right)$ dengan implementasi upah minimum kabupaten (y) murni atau tidak, dilakukan dengan membandingkan sig. dengan $\alpha(0,05)$. Jika probabilitas $\geq \alpha(0,05)$ berarti korelasinya tidak murni, dan jika probabilitasnya $<\alpha(0,05)$ berarti korelasinya murni. Oleh karena nilai sig. $(, 000)<\alpha(0,05)$ berarti korelasinya murni. Dengan demikian X1, X2, X3 benar-benar berkorelasi dengan implementasi upah minimum kabupaten (y), sebagaimana tabel berikut:

Tabel 8. Korelasi Parsial

\begin{tabular}{lcccc}
\hline No & Korelasi & $\begin{array}{c}\text { Variabel } \\
\text { Pengontrol }\end{array}$ & $\begin{array}{c}\text { Nilai Koefisien } \\
\text { Korelasi Parsial }\end{array}$ & Sig \\
\hline & & & & \\
1. & $\mathrm{X}_{1}$ dengan $\mathrm{Y}$ & $\mathrm{X}_{2}$ dan $\mathrm{X}_{3}$ & 0,270 &, 000 \\
2. & $\mathrm{X} 2$ dengan Y & $\mathrm{X}_{\text {dan } \mathrm{X} 3}$ & 0,326 &, 000 \\
3. & $\mathrm{X}_{3}$ dengan $\mathrm{Y}$ & $\mathrm{X}_{1}$ dan $\mathrm{X}_{2}$ & 0,367 &, 000 \\
\hline
\end{tabular}

\section{Uji Korelasi Ganda}

Berdasarkan tabel anova diketahui bahwa pengaruh tersebut dapat dikatakan signifikan karena nilai F hitung sebesar 16.131 dengan nilai Sig. sebesar 0,000 atau lebih rendah dari 0,05. Oleh karena itu, disimpulkan bahwa terdapat pengaruh secara bersama-sama yang positif dan kuat serta signifikan antara variabel perilaku hubungan antar organisasi pelaksana $\left(\mathrm{x}_{1}\right)$, variabel perilaku implementor $\left(\mathrm{x}_{2}\right)$ dan perilaku kelompok sasaran $\left(\mathrm{x}_{3}\right)$ dengan Implementasi Upah Minimum Kabupaten (y). 


\section{Uji Regresi}

\section{Pengaruh Perilaku Hubungan Antar Organisasi Pelaksana Terhadap Implementasi Upah Minimum Kabupaten}

Hasil penelitian menunjukkan bahwa perhitungan persamaan regresi linier sederhana variabel perilaku hubungan antar organisasi pelaksana adalah $\mathrm{Y}=28,240+0,991 \mathrm{X}_{1}$ persamaan regresi sederhana tersebut dapat diinterprestasikan bahwa perilaku hubungan antar organisasi pelaksana terbukti Signifikannya dalam penelitian ini tampak sesuai dengan fakta empirik di lokasi penelitian. Organisasi yang secara langsung dengan permasalahan UMK adalah SPSI/PUK, Apindo, organisasi tersebut mempunyai peran masing-masing yang sesuai dengan kepentingannya.

\section{Pengaruh Perilaku Implementor Dengan Keberhasilan Implementasi Upah Minimum Kabupaten.}

Hasil penelitian menunjukkan bahwa perhitungan persamaan regresi linier sederhana variabel perilaku hubungan antar organisasi pelaksana adalah $Y=23,820+1,343 x_{2}$ persamaan regresi sederhana tersebut dapat diinterprestasikan bahwa perilaku implementor terbukti Signifikannya dalam penelitian ini tampak sesuai dengan fakta empirik di lokasi penelitian, implementor dalam penelitian ini adalah pemerintah sebagai pemegang regulator tentang UMP dan Pengusaha atau Apindo sebagai fihak yang harus melaksanakan kebijakan UMK. Beberapa kendala yang muncul di fihak Apindo yaitu sebagian pengusaha belum menjalankan perusahaan secara profesional. Sehingga masih terdapat dobel standar pembayaran upah pekerja. Peran pemerintah seharusnya lebih banyak pada penegakan aturan kebijakan UMK, tidak cukup hanya dalam sosialisasi kebijakan tersebut karena pengusaha dan pekerja sudah mengetahui baik dimedia massa maupun diantara pekerja itu sendiri.

\section{Pengaruh Perilaku Kelompok Sasaran Terhadap Implementasi Upah Minimum Kabupaten}

Hasil penelitian menunjukkan bahwa perhitungan persamaan regresi linier sederhana variabel perilaku kelompok sasaran adalah $\mathrm{Y}=14,640+1,546 \mathrm{X}_{3}$ persamaan regresi sederhana tersebut dapat diinterprestasikan bahwa perilaku kelompok sasaran terbukti Signifikannya dalam penelitian ini tampak sesuai dengan fakta empirik di lokasi penelitian. Kelompok sasaran dalam penelitian ini adalah pekerja yang juga menjadi pengurus PUK/SPSI maka terdapat karakter yang hampir sama dari individu pekerja dengan tingkat pendidikan yang rendah dan kompentensi minim maka potensi untuk dieksploitasi oleh pengusaha sangat tinggi. Tingkat produktivitas rendah mempengaruhi penilaian dan penghargaan dari pengusaha baik dalam UMK maupun tunjangan lainnya. 


\section{Pengaruh Perilaku Hubungan Antar Organisasi Pelaksana (X1), Perilaku Implementor} (X2) Dan Perilaku Kelompok Sasaran (X3) Dengan Implementasi Upah Minimum

\section{Kabupaten (Y)}

Pada hasil penelitian menunjukkan bahwa perhitungan persamaan regresi linier berganda adalah $Y=16.131+0,300 X_{1}+0,510 X_{2}+0,626 X_{3}$ dengan demikian dari ketiga variabel, yaitu variabel perilaku kelompok sasaran di dalam korelasinya memberikan pengaruh pada taraf yang kuat terhadap variabel keberhasilan Implementasi Upah Minimum Kabupaten. Sebab, jika variabel perilaku kelompok sasaran mengalami kenaikan sebesar satu persen, pengaruh terhadap keberhasilan Implementasi Upah Minimum Kabupaten sebesar 0,626 persen. Hasil uji koefesien determinasi diketahui bahwa 80,1 persen keberhasilan Implementasi Upah Minimum Kabupaten di dominasi oleh faktor perilaku kelompok sasaran. Jadi dapat disimpulkan bahwa apabila dilihat dari hasil analisis regresi berganda faktor perilaku kelompok sasaran yang paling mempengaruhi keberhasilan implementasi kebijakan Implementasi Upah Minimum Kabupaten Implementasi Upah Minimum Kabupaten.

\section{KESIMPULAN}

Terdapat pengaruh yang signifikan antara perilaku hubungan antar organisasi dengan implementasi upah minimum kabupaten dengan arah positif, yang berarti semakin baik perilaku hubungan antar organisasi maka baik pula implementasi upah minimum kabupaten. Kemudian, terdapat pengaruh yang signifikan yakni antara perilaku implementor dengan keberhasilan implementasi upah minimum kabupaten dengan arah positif, yang berarti semakin baik perilaku implementor maka baik pula implementasi Upah Minimum Kabupaten. Selanjutnya, terdapat pengaruh yang signifikan antara perilaku kelompok sasaran dengan keberhasilan implementasi upah minimum kabupaten dengan arah positif, yang berarti semakin baik perilaku kelompok sasaran maka baik pula implementasi Upah Minimum Kabupaten. Selain itu, terdapat pengaruh bersama-sama yang signifikan antara perilaku hubungan antar organisasi, perilaku implementor dan perilaku kelompok sasaran dengan keberhasilan implementasi upah minimum kabupaten dengan arah positif, yang berarti semakin baik perilaku perilaku hubungan antar organisasi, perilaku implementor dan perilaku kelompok sasaran maka baik pula implementasi upah minimum kabupaten.

\section{DAFTAR PUSTAKA}

Agus P., E. d. (2012). Implementasi Kebijakan Publik. Yogyakarta: Gadjah Mada University Press. Agustino, L. (2006). Dasar-Dasar Kebijakan Publik. Jakarta: Alphabeta.

Algifari. (2002). Analisa Regresi. Yogyakarta: BPFE. 
Anom, E. (Maret 2014). Kebijakan Upah Buruh Minimum Sektoral di Kabupaten Tangerang Perspektif Komunikasi Politik. Jurnal Komunikologi, Volume 11 Nomor 1.

Arikunto, S. (2002). Prosedur Penelitian Suatu Pendekatan Praktek . Jakarta: Rineka Cipta.

Budiyono. (2007). Penetapan Upah Minimum dalam Kaitan dengan Upaya Perlindungan Bagi Pekerja/Buruh dan Perkembangan Perusahaan. Thesis Pasca Sarjana Fakultas Hukum Universitas Diponegoro, Semarang.

Effendi, M. S. (1995). Metode Penelitian Survei. Jakarta: Edisi Revisi , PT. Pustaka LP3ES.

Erlina, S. M. (2007). Metodologi Penelitian. Medan: USU Press.

Ghozali, I. (2005). Analisis Multivariat dengan Program SPSS. Semarang: Universitas Diponegoro.

Hadi, S. (1987). Metodologi Reseach. Yogyakarta: Andi Offset.

Islamy, I. M. (1997). Kebijakan Suatu Proses Politik. Jakarta: PT. Elex Media Komputindo.

Islamy, M.-P. P. (995). Prinsip-Prinsip Perumusan Kebijakan Negara. Jakarta.

Korten, D. d. (1998). Pembangunan Berdimensi Kerakyatan. Bandung: Yayasan Obor.

Kurniawan, L. J. (2015). Negara Kesejahteraan dan Pelayanan Sosial. Malang: Intrans Publishing.

Moeleong, J. l. (2002). Analisis Data. Jakarta: PT Persada Mulya.

Nugroho, R. (2014). Public Policy Teori,Manajemen,Dinamika,Analisis,Konvergensi dan Kimia Kebijakan. Jakarta: PT. Gramedia.

Pratomo, D. S. (Oktober 2011). Kebijakan Upah Minimum untuk Kebijakan yang berkeadilan: Tinjauan UUD1945. Journal of Indonesia Applied Economics , Volume 5 nomor 2.

Purwanto, E. A. (2012). Implementasi Kebijakan Publik Konsep dan Aplikasinya di Indonesia. Yogyakarta: Gava Media.

Riduwan. (2005). Skala Pengukuran Variabel-Variabel Penelitian. Bandung: Alfabeta.

RN., D. (2006). Kebijakan Publik: Formulasi, Implementasi dan Evaluasi. Jakarta: Elex Media Komputindo.

Saifuddin, A. (1992). 6. Saifuddin Azwar, ( 1992), Reliabilitas dan Validitas, Edisi keenam, Pustaka Pelajar, Yogyakarta. Yogyakarta: Pustaka Pelajar.

Santosa, S. (2001). Mengolah Data Statistik Secara Profesional. Jakarta: PT. Alex Media Komputindo.

Soegiarto Soekidjan, S. K. (2009). Komitmen Organisasi Sudahkah Menjadi Bagian Dari Kita. Dibuka pada: www.kesad.mil.id/category/berita/ditkesad.

Subarsono. (2011). Analisis Kebijakan Publik. Yogyakarta: Pustaka Pelajar.

Sudjana, E. (2002). Buruh Menggugat Perspektif Islam. Jakarta: PUstaka Sinar Harapan. 
Sugiyono. (2011). Statistik untuk Penelitian. Bandung: Alfabeta.

Sunggono, B. ( 1994.). Hukum dan Kebijaksanaan Publik. Jakarta: Sinar Grafika.

Thoha, M. (2005). Perilaku Organisasi, Konsep dasar dan Aplikasinya. Jakarka: Raja Grafindo Persada.

Wahab, S. A. (2012). Analisis Kebijakan dari Formulasi ke Penyusunan Model-Model Implementasi Kebijakan Publik. Jakarta: Bumi Aksara.

Warto, A. I. (2014). Analisa Data Kuantitatif. Purwokerto: Stain Press.

Wibawa, S. (1994). Evaluasi Kebijakan Publik. Jakarta: Grafindo.

Widodo. (2001). Implementasi Kebijakan. Bandung: CV. Pustaka Pelajar.

Winarno, B. (2008). Kebijakan Publik Teori dan Proses. Yogyakarta: MedPress.

Winarno, B. P. (2014). Kebijakan Publik Teori, Proses, dan Studi Kasus. Jakarta: PT. Buku Seru.

\section{Sumber Jurnal Penelitian}

Suparjan dan Hempri Suyatno (2002): "Kebijakan Upah Minimum yang Akomodatif”

Rekson Silaban dalam bukunya " Reposisi Gerakan Buruh, Peta Jalan Gerakan Buruh Indonesia Pasca Reformasi” (2009)

Lestari Handayani (2002) : "Implementasi Penetapan Kebijakan Upah Minimum Kabupaten" (Studi Kasus di Kecamatan Sayung Kabupaten Demak)

Grendi Hendrastomo (2010) : "Menakar Kesejahteran Buruh : Memperjuangkan Kesejahteraan Buruh di antara Kepentingan Negara dan Korporasi"

Ranggi Ade Febrian dan Isril (2007) dalam artikel “Karya Tulis Imiah untuk Jurnal-Jurnal Ilmu Sosial"

Tartopo Sunarto (2004): “Studi Kebijakan Upah Minimum dalam Pelaksanaan Otonomi Daerah di Jawa Tengah"

Andri Novius (2007) "Fonomena Kesejahteran Buruh/Karyawan di Indonesia”

Wildan Hakim (2012), "Strategi Komunikasi Serikat Pekerja Pers dalam Menyelesaikan Konflik Hubungan Industrial di Perusahaan Media"

\section{Sumber Perundang-Undangan}

Dinas Tenaga Kerja, T. d. (2013). Data Base Tenaga Kerja Daerah Kabupaten Kebumen Tahun 2013. Kebumen.

Keputusan Gubernur Jawa Tengah nomor: 560/66 Tahun 2016 tentang Upah Minimum Pada 35 (tiga puluh lima) Kabupaten Kota.

Undang-Undang Nomor 13 Tahun 2013 Tentang Ketenagakerjaan.

\section{Sumber Internet}

www.kppod.org. (Maret-April 20013). Kesejahteraan Buruh dan Daya Saing Perusahaan. KPPOD 